\title{
魚体表面の粘性物質に関する研究一III. 各種魚類体表面粘性物質の構成ア之ノ酸
}

榎本則行・長尾忠明・富安行雄

(1960 年 8 月 31 日受理)

\section{STUDIES ON THE EXTERNAL MUCOUS SUBSTANCE OF FISHES-III. IDENTIFICATION OF AMINO ACIDS IN THE MUCOUS PROTEIN FROM SOME FISHES BY PAPER CHROMATOGRAPHY}

\author{
Noriyuki Enомото, Tadaaki Nagao and Yukio Tomryasu*
}

\begin{abstract}
Amino acid pattern in acid hydrolyzate of the protein from the external mucous substance of 11 kinds of fishes (2 fresh water and 9 sea water fishes) was examined by paper chromatography. All the samples tested gave 16 spots of amino acids and 1 spot of unknown substance with ninhydrin (Fig. 1). As shown in Table 1, in which relative amounts of amino acids estimated roughly from the area and the color intensity of the spots are given, the mucous protein of these fishes seemed to be quite similar in amino acid composition except Dasyatis alcajei, the protein of which differed considerably from that of the others, being poorer in leucine, alanine, phenylalanine and arginine, and richer in threonine. Raja hollandi was different from Dasyatis akajei in the amino acid composition, the former being rather similar to teleosts although they are both Elasmobranch fishes.
\end{abstract}

魚類の体表面粘性物質（以下粘質物と略称する）はその粘度，かたさ，你体表面への附着の仕方などが焦

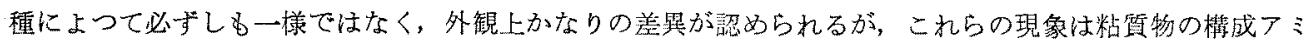
ノ酸，構成梼その他の成分と関連性を有するのではないか子推察される。著者等 ${ }^{112)}$ は先にドジョウ，マア ナゴの粘質物の化学的性質について比較検討した。この両者は權成糖に抢いて明らかな差翼を認めたが，楧 成アミノ酸の種類は全く同じであつた。しかし僅か 2 種の息についての結果のみで粘質物の全般について考

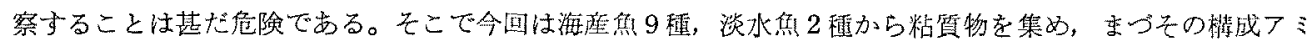
ノ酸を paper chromatography によつて調べたので，その結果について報告する。

\section{実 験 方 法}

\section{1. 魚 種}

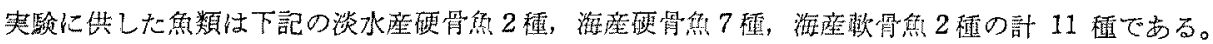
ウナギ (eel) Anguilla japonica TEMmINcK et SChLEGeL

カムルチー (snake-head fish) Channa argus (CANTOR)

フカアマダイ (blanquillos) Branehiostegus japonicus japonicus (HoUTTUYN)

ミシマオコゼ (star-gazer) Uranoscopus japonicus HoUtTUYN

サバフグ (puffer) Lagocephalus lunaris (BLOCH et SCHNEIDER)

ホウボウ (gurnard) Chelidonichthys kumu (LESSON et GARNOT)

ガソゾービラメ (flat-fish) Pseudorhombus cinnamoneus (TEMMINCK et SCHLEGEL)

* 九州大学農学部水産化学教空 (Lab. Fish. Chem. Fac. Agr., Kyushu Univ., Fukuoka, Japan). 


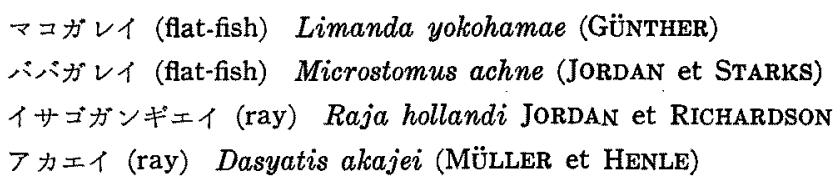

この内，ウナギカカムルチー，サバフグは活魚を用い，その他のものは福岡魚市場で入手した死魚である。

\section{2. 体表面粘質物の採取法}

前報1に準じて行なつたが，エイ，ヒラメ類の上うな大型魚は alcohol 浸漬を行なかないで体表面からか きとつた。alcohol, acetone, ether で順次貺水して粗粉末を得，これを前報”にしたがつて $0.1 \% \mathrm{NaOH，}$ 稀 $\mathrm{HCl}$ で処理後, 再び脱水して精製粉末とした。

\section{Paper chromatography}

精隼粉末に 50 倍量の $8 \mathrm{~N}-\mathrm{HCl}$ を加穴て 10 時間加水分解後, 減圧浱縮をくり返してできるだけ $\mathrm{HCl}$ を

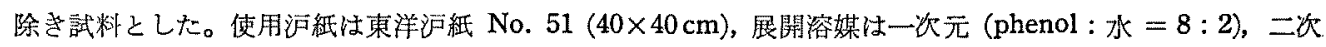
元 $(n-\mathrm{Bu}(\mathrm{OH}): \mathrm{Ac}(\mathrm{OH}):$ 水 $=4: 1: 2)$ を用い, ninhydrin で呈色せしぬた。

\section{実 験 結 果}

供試魚 11 種の粘質物の展開結果から同定し得たアミノ酸の種類は, cystine, lysine, histidine, glutamic acid, serine, aspartic acid, arginine, glycine, threonine, alanine, tyrosine, valine, methionine, phenylalanine, leucine, proline の 16 種で, 他に不明のninhydrin による呈色物質が一つ存在した。魚種に よつては histidine の存在がやや不明確なるのがあつた。これらの同定し得たアミノ酸の種類は, 既報 ${ }^{122} の$ 2 種の魚と同一で魚種別による差暴はないるのと考えられる。展開例としてホウボウ、フカエイの結果を Fig. 1 に示した。
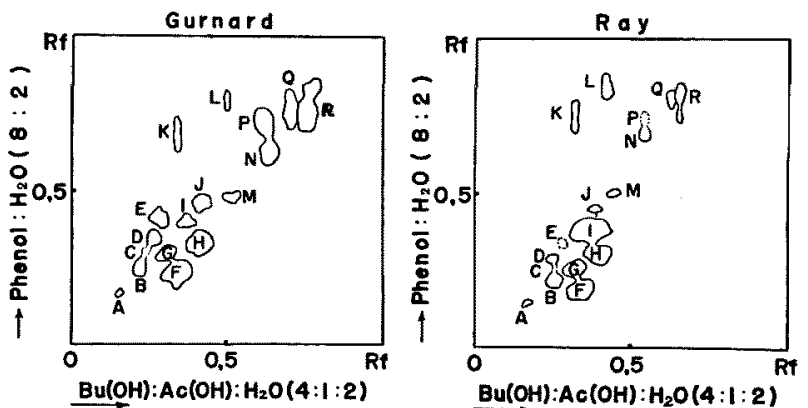

Fig. 1. Two-dimensional paper chromatogram showing the amino acid pattern of the external mucous substance, exemplified by gurnard, Chelidonichthys kumu, and ray, Dasyatis akajei.
A Cystine
B Lysine
C Histidine
D Glycine
E Arginine
F Aspartic acid
G Serine
H Glutamic acid
I Threonine

$\begin{array}{ll}\text { J } & \text { Alanine } \\ \text { K } & ? \\ \text { L } & \text { Proline } \\ \text { M } & \text { Tyrosine } \\ \text { N } & \text { Valine } \\ \text { P } & \text { Methionine } \\ \text { Q } & \text { Phenylalanine } \\ \text { R } & \text { Leucine }\end{array}$

同定し得たてミノ酸の種類には差がなかつたが, 沪紙上の spot の大きさ, 呈色度には差が認められたの で,これによつて量的関係を推定したのが Table 1 である。この量的な差は啟密な定量法にはよらず官能 
Table 1. Relative amino acid composition of the external mucous substance.

\begin{tabular}{|c|c|c|c|c|c|c|c|c|c|c|c|c|c|}
\hline & $\begin{array}{c}4 \\
\Phi \\
\Delta\end{array}$ & 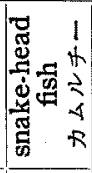 & 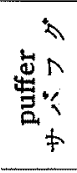 & 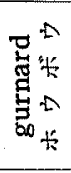 & 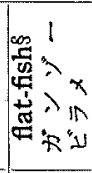 & 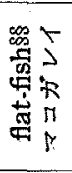 & 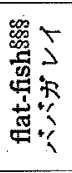 & 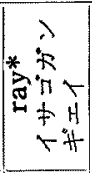 & \begin{tabular}{c}
$\leftarrow$ \\
$*$ \\
$*$ \\
\multirow{2}{*}{$H$} \\
$N$
\end{tabular} & 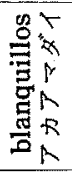 & 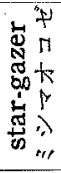 & 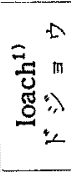 & $\begin{array}{l}\pi \\
5 \\
80 \\
8 \\
8\end{array}$ \\
\hline glycine & $H$ & $H$ & 世 & $\#$ & H & \# & 井 & $H$ & \# & $H$ & \# & H & $H$ \\
\hline alanine & H & \# & $H$ & H & H & H & $H$ & $H$ & + & H & H & H & \# \\
\hline valine & H & \# & H & H & \# & H & H & $H$ & $H$ & H & H & H & $H$ \\
\hline leucine & 册 & 曲 & 曲 & 册 & WH & 曲 & 曲 & 册 & $H$ & 挫 & 曲 & 曲 & HI \\
\hline serine & $\#$ & H & H & $H$ & H & 世 & H & H & H & H & H & $H$ & $\#$ \\
\hline threonine & H & $H$ & H & H & H & H & $H$ & $H$ & HEl & $H$ & $H$ & HI & $H$ \\
\hline cystine & + & + & + & + & + & + & H & + & + & $H$ & + & + & + \\
\hline aspartic acid & 世曲 & Wl & 卅 & 曲 & 曲 & 曲 & H⿻ & 卅 & 册 & 曲 & HII & HII & 册 \\
\hline $\begin{array}{l}\text { glutamic } \\
\text { acid }\end{array}$ & till & H & $H$ & HItt & 曲 & HAt & 世林 & 册 & HEt & 册 & HWt & HH & 册 \\
\hline tyrosine & $H$ & $H$ & + & $H$ & + & + & + & + & + & + & + & + & + \\
\hline $\begin{array}{l}\text { phenyl- } \\
\text { alanine }\end{array}$ & H & $H$ & $H$ & H & H & \# & $H$ & $H$ & + & H & H & H & $H$ \\
\hline proline & $H$ & + & + & $H$ & \# & $H$ & $H$ & + & $H$ & + & + & $H$ & $H$ \\
\hline arginine & $H$ & $H$ & 井 & \# & 曲 & $H$ & \# & $H$ & $(+)$ & H & H & $H$ & $H$ \\
\hline histidine & $(+)$ & $(+)$ & $(+)$ & $(+)$ & + & + & $(+)$ & + & $(+)$ & $(+)$ & + & + & + \\
\hline lysine & H & H & 册 & $H$ & \# & $H$ & H & HI & H & H & H & 册 & $H$ \\
\hline methionine & H & $H$ & + & H & \# & + & $(+)$ & + & $(+)$ & + & + & + & \# \\
\hline$?$ & + & $(+)$ & $(+)$ & + & + & + & + & + & + & $(+)$ & + & + & + \\
\hline
\end{tabular}

\& Pseudorhombus cinnamoneus, \$\$ Limanda yokohamae, \$\&\$ Microstomus achne.

* Raja hollandi, ** Dasyatis akajei.

册: very strong color intensity, $H$ : strong color intensity, $H$ : medium color intensity,

+ : weak color intensity, $(+)$ : very weak color intensity.

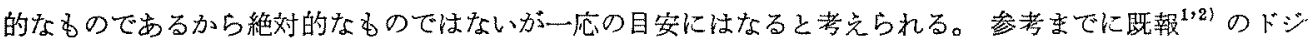
ヨウママアナゴの結果も併記した。この比較は個々の魚の粘質物のアミノ酸組成にのみ適用乙得るものであ. つて, 異つた魚種間のフミノ酸組成の比較はできない。フカエイのみが特異な量的関倸を示しているが，そ の他の魚注共通点が多い上5である。

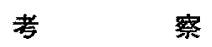

体表面粘質物が多い魚は運動性が比較的不活発なものが多いが，本実験に用いた魚種もまたこの例に洩れ ない。供試各魚は棲息環境が淡水，海水に大別され，分類学的には軟骨魚類，硬骨魚類の両方を含んでいる。 硬骨魚類には多くの分類群があるが，それらの代表的なものも活注含まれている。体表面の鱗をくらべてみ ると，全く存在しないもの（マフナゴ）、活とんど退化したもの（ウナギ，ドジョウサバフグ，エイ類）, 小型ないし中型の鱗をるつもの (本ウボウ, カレイ, ヒラメ類), 完全な鱗をるつもの(アカアマダイ, カム ルチー) などがあり，種々の観点から多種多稊の魚を集めたが，これらの粘質物の $0.1 \% \mathrm{NaOH}$ 可溶部に

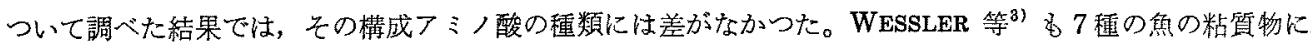
ついてアミノ酸組成を paper chromatography によつて調へ， ray を除いて差がなかつたと述べ ray の粘 質物は tyrosine を欠くと報告している。その ray は Raja sp. と記述しているからイサゴガンギェイに 近绿のるのと思われるが，著者等の結果ではアカエイ，イサゴガンギエイにそれぞれ tyrosine を認めた。 WESSLER 等 ${ }^{3)}$ の報告は粘啠物の謂䌘法が不明確なので, 著者等の結果と比較するのは当を得ないか子しれ ないが，エイを除けば著者等と WESSLER 等”)の結果とはよく一致する。

構成アミノ酸の量的関倸を Table 1 から推定すると, glutamic acid, aspartic acid の酸性アミノ酸括 
よび leucine が各钩䄽を避じて多く, valine, arginine, threonine, alanine, phenylalanine, serine, lysine が中符度の含量を示している。少ないるのは cystine, tyrosine, histidine, proline で methionine は奥種 による美がはげしいようでする。

アカエイには threonine が多く leucine, alanine, phenylalanine, arginine が少い点で, 特粠的なアミ

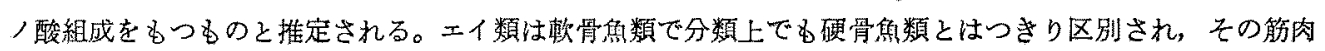
も尿素が多いことが知られているので，上述のアミノ酸組成の差異も一応らなつけるが，同じェイ類ですイ サゴガンギェイはアカエイとの類似点がほとんどなく，むしろ硬骨與のアミノ酸組成とよく似ているのは興 味あるところである。

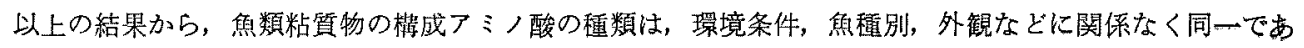
ると考文る。粘質物のアミノ酸組成の詳細については後報にゆづりたい。

\section{摘要}

淡水焦 2 種，海産焦 9 種の体表面粘性物質を集め，その棈成アミノ酸を paper chromatographyによつ て比较檢討した。その結果，揹成アミノ酸の種類は各焦種とも同一で 17 構（内未同定 1 ）からなることを

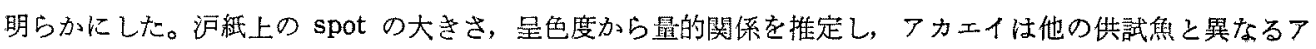

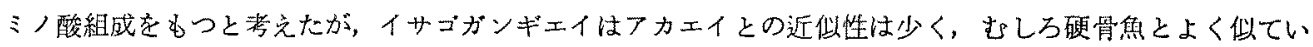
ることを指摘した。

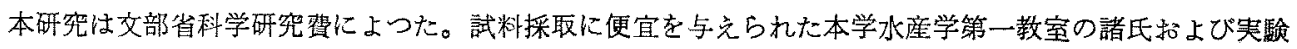
水力された田中茩，三浦武の网氏に感謝する。

\section{文献}

1) 榎本則行 ·富安行雄：本誌，26，739 (1960).

2) 榎本則行・長尾忠明・富安行雄：本誌, 26, 745 (1960).

3) Wessler, E. and Werner, I.: Acta Chem. Scand., 11, 1240 (1957). 